\title{
PENERAPAN MODEL PEMBELAJARAN KOOPERATIF TIPE STAD (STUDENT TEAMS ACHIEVEMENT DIVISION) UNTUK MENINGKATKAN HASIL BELAJAR SISWA
}

\author{
Akhmad Suyono \\ Universitas Islam Riau \\ gerhanabestari@yahoo.com
}

\begin{abstract}
This research was conducted in order to determine improving student learning outcomes in the class X-1 P-Marpoyan SMA YLPI Pekanbaru through the application of cooperative learning model STAD (Student Teams Achievement Division). This study was conducted from February to March 2010. The subjects were students of class X-1 at the high school YLPI P-Marpoyan Pekanbaru consist of 36 students. Collecting data use questionarre and observation. The result shows that the application of cooperative learning model STAD (Student Teams Achievement Division) can improve the learning outcomes of students of class X-1 at the high school YLPI P-Marpoyan Pekanbaru.
\end{abstract}

Keywords: Cooperative Learning STAD type, Achievement.

\begin{abstract}
Abstrak: Penelitian ini dilaksanakan dengan tujuan untuk mengetahui peningkatan hasil belajar siswa kelas X-1 di SMA YLPI P-Marpoyan Pekanbaru melalui penerapan model pembelajaran kooperatif tipe STAD (Student Teams Achievement Division). Penelitian ini dilaksanakan pada bulan Februari sampai Maret 2010. Subjek penelitian ini adalah siswa-siswi kelas X-1 di SMA YLPI P-Marpoyan Pekanbaru yang berjumlah 36 siswa. Pengumpulan data menggunakan angket dan observasi. Hasil penelitian menunjukkan bahwa penerapan model pembelajaran kooperatif tipe STAD (Student Teams Achievement Division) dapat meningkatkan hasil belajar siswa kelas X-1 di SMA YLPI P-Marpoyan Pekanbaru.
\end{abstract}

Kata kunci : Pembelajaran kooperatif tipe STAD, Hasil Belajar

Pelajaran ekonomi adalah salah satu ilmu sosial yang mempelajari berbagai perilaku ekonomi terhadap keputusan-keputusan ekonomi yang dibuat. Ilmu ekonomi diperlukan sebagai kerangka berfikir untuk dapat melakukan pilihan terhadap berbagai sumber daya yang terbatas untuk memenuhi kebutuhan manusia yang terbatas. Dengan belajar ekonomi diharapkan siswa dapat memiliki sikap bijak dan rasional bagi diri sendiri, rumah tangga, masyarakat dan Negara.

Proses pembelajaran yang dilakukan untuk mencapai tujuan-tujuan pembelajaran hendaknya banyak melibatkan peran aktif siswa dalam kegiatan 
pembelajaran. Apabila proses belajar baik diharapkan hasil belajar siswa juga baik. Salah satu tujuan pengajaran adalah tingginya pencapaian hasil belajar siswa. Akan tetapi dari hasil wawancara dengan salah satu guru bidang studi ekonomi di SMA YLPI P-Marpoyan Pekanbaru, diperoleh informasi bahwa hasil belajar ekonomi di sekolah tersebut masih rendah. Hal ini dapat dilihat dari hasil ulangan harian siswa pada materi Inflasi di kelas $\mathrm{X}_{1}$ pada semester ganjil tahun ajaran 2009 / 2010 yaitu dengan jumlah siswa 36 orang yang terdiri dari 9 orang siswa laki-laki dan 27 siswa perempuan, hanya 23 siswa atau $64 \%$ yang mencapai ketuntasan, dan yang belum mencapai ketuntasan berjumlah 13 siswa atau 36\%, sedangkan Kriteria Ketuntasan Minimal (KKM) yang ditetapkan di sekolah pada mata pelajaran ekonomi adalah 65,00 dengan presentase $65 \%$.

Menurut informasi dari guru bidang studi, faktor yang menyebabkan rendahnya hasil belajar siswa dikarenakan siswa kurang memperhatikan pelajaran yang disampaikan, kurang aktif dalam proses belajar mengajar, penggunaan media yang belum maksimal dan minat baca yang masih rendah. Sehubungan dengan hal tersebut, rendahnya hasil belajar juga dipengaruhi oleh cara penyajian atau metode mengajar guru. Kondisi ini senada dengan pernyataan Noehi Nasution, dkk dalam Syaiful Bahri Djamarah (2002:141) yang memandang belajar itu bukanlah suatu aktifitas yang berdiri sendiri. Mereka berkesimpuan ada unsur-unsur lain ikut terlibat langsung di dalamnya, yaitu input berupa pengalaman belajar tertentu dalam proses belajar mengajar dengan harapan dapat berubah menjadi keluaran dengan kualifikasi tertentu.

Hal senada dengan yang dikemukakan oleh Syah (2007:247) secara global, faktorfaktor yang mempengaruhi belajar seseorang dapat dibedakan menjadi tiga macam yaitu faktor internal (faktor dari dalam diri siswa) yakni keadaan/ kondisi jasmani dan rohani siswa, faktor eksternal (faktor dari luar diri siswa) yakni kondisi di lingkungan sekitar siswa, dan faktor pendekatan belajar yakni jenis upaya belajar siswa yang meliputi strategi dan metode yang digunakan untuk melakukan kegiatan pembelajaran. Mencermati permasalahan di atas perlu maka dilakukan perbaikan. Sebagai fasilitator dan motivator guru dapat melakukan pembaharuan dan perbaikan dalam pembelajaran, karena merasa tidak puas terhadap situasi dan hasil belajar siswa, maka digunakan suatu model pembelajaran kooperatif tipe STAD. STAD merupakan salah satu metode pembelajaran kooperatif yang paling sederhana dan merupakan model yang paling baik 
untuk permulaan bagi para guru yang baru menggunakan pendekatan kooperatif. Menurut Slavin (2008) pembelajaran kooperatif adalah suatu model pembelajaran dimana siswa dalam kelompok kecil terdiri dari 4-5 orang siswa belajar dan bekerja secara kolaborasi dengan struktur heterogen. Selanjutnya Slavin menjelaskan bahwa STAD terdiri dari lima unsur komponen utama yaitu: presentasi kelas, tim, kuis, skor kemajuan individual,dan penghargaan kelompok (rekognisi tim). Slavin juga menyatakan bahwa pembelajaran kooperatif tipe STAD mempunyai keunggulan yaitu: (1) dapat meningkatkan kemampuan akademik siswa; (2) semua kelompok mempunyai tugas; (3) siswa dilatih untuk mengembangkan keterampilan sosial; (4) mendorong siswa menghargai pendapat orang lain; (5) melatih siswa untuk berani berbicara didepan kelas; (6) dapat meningkatkan rasa persaudaraan; (7) ada interaksi langsung antara siswa dengan siswa, siswa dengan guru. Sedangkan kelemahannya adalah memerlukan waktu yang lama dan kemungkinan ada siswa yang kurang aktif dalam kelompok. Berdasarkan analisa sementara menunjukkan bahwa melalui penerapan metode kooperetif STAD diduga dapat meningkatkan hasil belajar siswa kelas $\mathrm{X}_{1}$ pada mata pelajaran ekonomi di SMA YLPI P-Marpoyan Pekanbaru.

\section{METODE}

Penelitian ini merupakan penelitian tindakan kelas yaitu melakukan tindakan dalam pembelajaran ekonomi yang berkerja sama dengan guru bidang studi. Penelitian ini dilakukan di kelas $X_{1}$ SMA YLPI Marpoyan Pekanbaru selama 2 bulan dari bulan Februari sampai bulan Maret 2010. Subjek penelitian ini adalah siswa kelas $\mathrm{X}_{1}$ SMA YLPI P-Marpoyan Pekanbaru di semester II (genap) pada tahun ajaran 2009 / 2010 dengan jumlah siswa 36 orang yang terdiri dari 9 siswa laki-laki dan 27 siswa perempuan.

Teknik analisis data yang digunakan adalah teknik analisis statistik deskriptif. Statistik deskriptif adalah statistik yang digunakan untuk menganalisa data dengan cara mendeskripsikan atau menggambarkan data yang telah terkumpul sebagaimana adanya tanpa bermaksud membuat kesimpulan yang berlaku untuk umum atau generalisasi (Sugiyono, 2009). Analisis data tentang aktifitas guru dan siswa didasarkan pada lembar pengamatan selama pelaksanaan tindakan. Pada lembar pengamatan akan terlihat kekurangan-kekurangan pada saat pelaksaaan tindakan. Kekurangan tersebut akan 
direfleksikan dan akan diperbaiki pada pertemuan berikutnya. Pelaksanaan tindakan dikatakan sesuai jika semua aktifitas penerapan model pembelajaran kooperatif tipe STAD terlaksana sebagaimana mestinya. Analisis data tentang pencapaian KKM pada materi konsumsi, tabungan dan investasi. Ketuntasan belajar individu, seorang peserta didik dipandang tuntas belajar jika ia mampu menyelesaikan, menguasai kompetensi atau mencapi tujuan belajar minimal 65\% dari seluruh pembelajaran. (Mulyasa, 2006 : 99)Sedangkan keberhasilan kelas dilihat dari jumlah peserta didik yang mampu menyelesaikan atau mencapai minimal $65 \%$, sekurang- kurangnya $85 \%$ dari jumlah peseta didik yang ada dikelas. (Mulyasa, 2006:99).

\section{HASIL DAN PEMBAHASAN}

Untuk mengetahui peningkatan hasil belajar ekonomi melalui model pembelajara kooperatif tipe STAD pada siswa kelas X-1 SMA YLPI Perhentian Marpoyan tahun pelajaran 2009/2010 dilakukan pengukuran terhadap hasil belajar yang dilihat dari daya serap siswa, ketuntasan belajar siswa yang terdiri dari ketuntasan individu dan ketuntasan klasikal, nilai perkembangan kelompok serta aktivitas siswa. Data penelitian ini diperoleh dari post test setiap akhir pertemuan dan hasil ulangan harian setiap sub materi usai dipelajari serta hasil observasi aktivitas siswa dan aktivitas guru pada setiap kali pertemuan. Data hasil post test dan ulangan harian sebagai data utama dan data aktivitas siswa dan aktivitas guru sebagai data pendukung.

Aktivitas siswa selama proses pembelajaran diamati dengan lembar observasi. Aktivitas yang diamati meliputi membaca buku teks siswa, mengerjakan LKS, bekerjasama dalam kelompok, menyampaikan pendapat dalam kelompok, bertanya kepada guru dan teman, dan menanggapi hasil diskusi. Hasil tersebut disajikan pada tabel dan grafik dibawah ini:

Tabel 1. Rata-rata Presentase Akhir Belajar Siswa Pada Siklus I dan II

\begin{tabular}{|c|c|c|c|c|c|c|c|}
\hline \multirow{4}{*}{$\begin{array}{l}\mathrm{N} \\
\mathbf{0}\end{array}$} & \multirow{4}{*}{$\begin{array}{c}\text { Aktivitas yang } \\
\text { diamati }\end{array}$} & \multirow{2}{*}{\multicolumn{3}{|c|}{$\begin{array}{c}\text { Siklus I } \\
\text { Pertemuan }\end{array}$}} & \multirow{2}{*}{\multicolumn{3}{|c|}{\begin{tabular}{|c|} 
Siklus II \\
Pertemuan
\end{tabular}}} \\
\hline & & & & & & & \\
\hline & & 1 & 2 & Rata- & 1 & 2 & Rata- \\
\hline & & $\begin{array}{c}\text { Jumlah } \\
(\%)\end{array}$ & $\begin{array}{c}\text { Jumlah } \\
(\%)\end{array}$ & $\begin{array}{l}\text { rata } \\
(\%)\end{array}$ & $\begin{array}{c}\text { Jumlah } \\
(\%)\end{array}$ & $\begin{array}{c}\text { Jumlah } \\
(\%)\end{array}$ & $\begin{array}{l}\text { rata } \\
(\%)\end{array}$ \\
\hline 1 & $\begin{array}{l}\text { Membaca buku } \\
\text { teks siswa }\end{array}$ & $25(70 \%)$ & $27(75 \%)$ & 72,5 & $30(83 \%)$ & $32(89 \%)$ & 79 \\
\hline 2 & $\begin{array}{l}\text { Mengerjakan } \\
\text { LKS }\end{array}$ & $34(94 \%)$ & $\begin{array}{c}36 \\
(100 \%)\end{array}$ & 97 & $34(94 \%)$ & $\begin{array}{c}36 \\
(100 \%)\end{array}$ & 97 \\
\hline 3 & Bekerjasama & $26(72 \%)$ & $28(78 \%)$ & 75 & $31(86 \%)$ & $34(94 \%)$ & 90 \\
\hline
\end{tabular}




\begin{tabular}{|c|l|c|c|c|c|c|c|}
\hline & dalam kelompok & & & & & & \\
\hline 4 & $\begin{array}{l}\text { Menyampaikan } \\
\text { pendapat dalam } \\
\text { kelompok }\end{array}$ & $24(67 \%)$ & $25(70 \%)$ & 68,5 & $29(81 \%)$ & $33(92 \%)$ & 86,5 \\
\hline 5 & $\begin{array}{l}\text { Bertanya kepada } \\
\text { guru dan teman }\end{array}$ & $22(61 \%)$ & $24(67 \%)$ & 64 & $28(78 \%)$ & $33(92 \%)$ & 85 \\
\hline 6 & $\begin{array}{l}\text { Menanggapi hasil } \\
\text { diskusi }\end{array}$ & $15(42 \%)$ & $19(53 \%)$ & 47,5 & $24(67 \%)$ & $33(92 \%)$ & 79,5 \\
\hline Rata-rata & 67,67 & 73,83 & 70,75 & 81,5 & 93,17 & 86,17 \\
\hline Kategori & Cukup & Cukup & Cukup & Baik & $\begin{array}{c}\text { Amat } \\
\text { baik }\end{array}$ & $\begin{array}{c}\text { Amat } \\
\text { baik }\end{array}$ \\
\hline
\end{tabular}

Sumber : Data Olahan

Rata-rata Persentase Aktivitas Belajar Siswa dalam Proses Pembelajaran Kooperatif Tipe STAD Pada Siklus I dan II dapat ditunjukkan pada grafik 1 berikut:

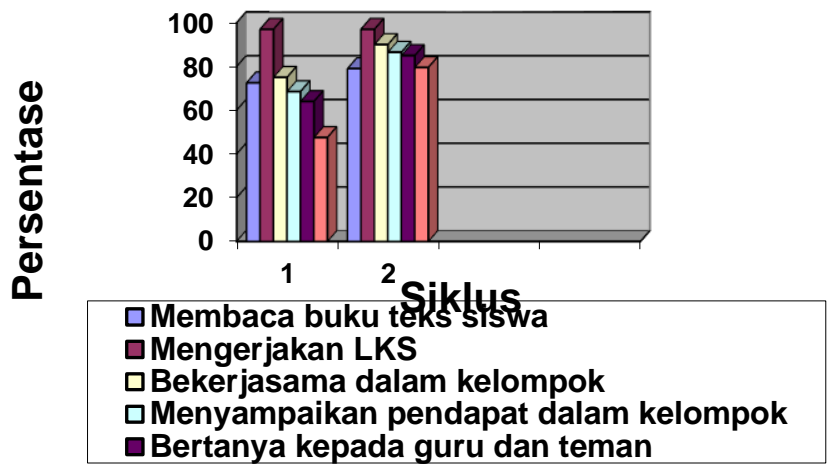

Grafik 1. Rata-rata Persentase Aktivitas Belajar Siswa Pada Siklus I dan II

\section{Aktivitas Belajar Siswa Pada Siklus I}

Berdasarkan tabel 1 dan grafik 1 terlihat bahwa aktivitas siswa pada pertemuan pertama berada pada kategori cukup dengan nilai rata-rata $67,67 \%$, kemudian untuk aspek bertanya dan menanggapi masih kurang. Kurangnya aktivitas siswa dalam bertanya disebabkan siswa masih takut untuk bertanya dan tidak percaya diri. Kemudian kurangnya aktivitas siswa dalam menanggapi hasil diskusi disebabkan siswa juga masih kurang percaya dalam mengemukakan ide-ide kelompoknya.

Namun untuk pertemuan kedua pada siklus I ini, aktivitas siswa sudah mulai mengalami peningkatan dengan nilai rata-rata $73,83 \%$, siswa sudah mulai bertanya pada guru jika mengalami kesulitan, kemudian siswa sudah mulai percaya diri dalam mengemukakan idenya dan menanggapi hasil diskusi kelompok. Namun kategori aktivitas siswa pada pertemuan kedua ini masih pada kategori cukup. Kemudian untuk aspek mengerjakan LKS dan bekarjasama dalam kelompok aktivitas siswa dari awal 
pertemuan sampai pada pertemuan kedua terlihat memuaskan meskipun terdapat beberapa siswa yang masih belum terbiasa bekerjasama dengan kelompoknya.

\section{Aktivitas Belajar Siswa Pada Siklus II}

Berdasarkan tabel 1 dan grafik 1, aktivitas siswa yang diamati pada siklus kedua mengalami peningkatan yang lebih baik dari pada siklus yang pertama. Secara umum aspek yang diamati pada siklus kedua ini mengalami peningkatan. Rata-rata persentase aktivitas belajar siswa pada pertemuan pertama 81,5\% dengan kategori baik, pada pertemuan kedua menjadi 93,17\% dengan kategori amat baik. Pada siklus kedua ini siswa sudah memahami metode pembelajaran kooperatif tipe STAD yang diterapkan. Semua aspek yang menonjol dalam metode pembelajaran kooperatif tipe STAD telah dimiliki oleh siswa.

\section{Nilai Perkembangan dan Penghargaan Kelompok}

Selama proses pembelajaran berlangsung, setiap siswa memperoleh nilai perkembangan baik individu maupun kelompoknya. Nilai perkembangan individu pada siklus I dihitung berdasarkan selisih nilai skor dasar dengan skor nilai ulangan harian I, sedangkan nilai perkembangan individu siklus II dihitung dari selisih skor ulangan harian I (sebagai skor dasar) dengan skor ulangan harian Siklus II. Kemudian jumlah skor test anggota kelompok dibagi dengan jumlah anggota kelompok, maka diperoleh rata-rata perkembangan dan dapat ditentukan penghargaan kelompoknya. Nilai perkembangan individu dari ulangan harian dapat dilihat pada tabel 2 di bawah ini:

Tabel 2. Nilai Perkembangan Individu Pada Ulangan Harian Siklus I dan II

\begin{tabular}{|c|c|c|c|c|c|}
\hline \multirow{2}{*}{ Siklus } & \multicolumn{4}{|c|}{ Nilai Perkembangan } & Jumlah \\
& 5 & 10 & 20 & 30 & Siswa \\
\hline I & - & $10(27,78 \%)$ & $14(38,89 \%)$ & $12(33,33 \%)$ & 36 \\
\hline II & - & $6(16,67 \%)$ & $24(66,66 \%)$ & $6(16,67 \%)$ & 36 \\
\hline
\end{tabular}

Sumber : Data Olahan

Berdasarkan data di atas, presentase siswa yang menyumbangkan nilai perkembangan 30 pada siklus I lebih banyak jika dibandingkan siklus II. Skor dasar yang digunakan untuk pembentukan kelompok siklus II lebih tinggi dari pada skor dasar pembentukan siklus I, karena skor dasar yang dipakai adalah skor dasar dari ulangan harian pada siklus I. Sedangkan untuk skor dasar pada siklus I digunakan skor dasar (hasil belajar sebelum tindakan) rendah, sehingga nilai perkembangan pada siklus pertama tinggi. 
Selanjutnya nilai ulangan harian I menjadi skor dasar pada siklus II dengan hasil yang lebih baik, sehingga nilai perkembangan siswa tidak setinggi pada siklus I. Penurunan nilai perkembangan juga disebabkan oleh tingkat kesulitan materi pelajaran. Jika pada siklus II skor dasar (hasil belajar sebelum tindakan), maka nilai perkembangan lebih tinggi dari pada siklus I.

\section{Aktivitas Guru}

Aktivitas guru dalam penerapan pembelajaran kooperatif tipe STAD diamati dengan lembar observasi. Hasil analisis aktivitas guru setiap pertemuan pada siklus I dan II dapat dilihat pada tabel dibawah ini.

Tabel 3. Aktivitas Guru Pada Siklus I dan II

\begin{tabular}{|c|l|c|c|c|c|c|c|}
\hline No & Kategori pengamatan & \multicolumn{2}{|c|}{ Siklus I } & \multicolumn{2}{c|}{ Siklus II } & \multicolumn{2}{c|}{ Skor } \\
\cline { 3 - 8 } & (I) & (II) & (I) & (II) & Siklus (I) & Siklus (II) \\
\hline 1 & $\begin{array}{l}\text { Menyampaikan informasi } \\
\text { materi pelajaran dan } \\
\text { membagikan Lembar } \\
\text { Kerja Siswa (LKS) }\end{array}$ & 4 & 5 & 5 & 5 & 20 & 25 \\
\hline 2 & $\begin{array}{l}\text { Membagi siswa dalam } \\
\text { bentuk kelompok }\end{array}$ & 5 & 5 & 5 & 5 & 25 & 25 \\
\hline 3 & $\begin{array}{l}\text { Membimbing siswa } \\
\text { dalam mengerjakan tugas } \\
\text { kelompok }\end{array}$ & 4 & 5 & 5 & 5 & 24 & 25 \\
\hline 4 & $\begin{array}{l}\text { Mengevaluasi hasil } \\
\text { presentasi siswa }\end{array}$ & 4 & 5 & 4 & 5 & 20 & 20 \\
\hline 5 & Memberikan Evaluasi & 4 & 5 & 5 & 5 & 20 & 25 \\
\hline 6 & $\begin{array}{l}\text { Memberikan } \\
\text { penghargaan kelompok }\end{array}$ & 4 & 5 & 5 & 8 & 25 \\
\hline \multicolumn{7}{|c|}{ Jumlah } \\
\hline \multicolumn{7}{|c|}{ Kategori } \\
\hline
\end{tabular}

Sumber: Data Olahan

Berdasarkan tabel 3, aktivitas guru pada siklus I dapat diketahui bahwa dari 6 kategori pengamatan aktivitas guru diperoleh rata- rata aktivitas guru 18,8\% dengan kategori cukup sempurna, terdapat 1 indikator yang dilakukan oleh guru dengan sangat sempurna, 4 indikator tindakan yang dilakukan guru sempurna dan 1 kategori tindakan yang dilakukan guru kurang sempurna yaitu pada saat memberikan penghargaan. Hal ini disebabkan karena guru belum dapat mengelola waktu dengan baik dalam proses belajar mengajar pada pertemuan pertama. Sedangkan pada pertemuan kedua 5 indikator dilakukan dengan sangat sempurna dan 1 indikator sempurna. 
Dari hasil pengamatan aktivitas guru siklus II dapat diketahui bahwa aktivitas guru menjadi lebih baik lagi. Hal ini dibuktikan bahwa semua tindakan guru yang dilakukan oleh guru sudah mencapai kategori sempurna. Perbandingan antara siklus I dan II terlihat jelas dari siklus I yang rata-ratanya 18,8 \% sedangkan pada siklus II ratarata yang diperoleh untuk aktivitas guru mencapai 24,1 \% dengan kategori sempurna.

\section{Daya Serap Siswa Pada Siklus I}

Hasil belajar siswa dilihat dari daya serap atau tingkat penguasaan pada siklus I dapat dilihat pada tabel berikut ini:

Tabel 4. Daya Serap Siswa pada Siklus I setelah Mengikuti Pembelajaran Kooperatif tipe STAD

\begin{tabular}{|c|c|c|c|c|c|}
\hline \multirow[t]{2}{*}{ No } & \multirow[t]{2}{*}{$\begin{array}{c}\text { Tingkat } \\
\text { Penguasaan }\end{array}$} & \multirow[t]{2}{*}{ Kategori } & \multicolumn{2}{|c|}{$\begin{array}{c}\text { Post Test Pertemuan } \\
\mathrm{Ke} \\
\end{array}$} & \multirow{2}{*}{$\begin{array}{c}\text { Ulangan } \\
\text { Harian } \\
\mathrm{N} \%\end{array}$} \\
\hline & & & $\frac{1}{\mathrm{~N} \%}$ & $\stackrel{2}{\mathrm{2} \%}$ & \\
\hline 1 & $84,00-100,00$ & Amat Baik & - & $4(11 \%)$ & - \\
\hline 2 & $74,00-83,00$ & Baik & $13(36 \%)$ & $12(33 \%)$ & $11(30,56 \%)$ \\
\hline 3 & $64,00-73,00$ & Cukup & $12(33 \%)$ & $14(39 \%)$ & $21(58,33 \%)$ \\
\hline 4 & $00,00-64,00$ & Kurang & $11(31 \%)$ & $6(17 \%)$ & $4(11,11 \%)$ \\
\hline \multirow{4}{*}{\multicolumn{3}{|c|}{$\begin{array}{c}\text { Jumlah } \\
\text { Rerata } \\
\text { Rata-rata } \\
\text { Kategori }\end{array}$}} & $36(100 \%)$ & $36(100 \%)$ & $36(100 \%)$ \\
\hline & & & 65 & 71,39 & \multirow{3}{*}{$\frac{71,94}{\text { Cukup }}$} \\
\hline & & & \multicolumn{2}{|c|}{68,20} & \\
\hline & & & \multicolumn{2}{|c|}{ Cukup } & \\
\hline
\end{tabular}

Sumber: Data Olahan

Berdasarkan tabel 4 diatas, dapat dilihat daya serap siswa melalui post test dan ulangan harian pada siklus I dengan Standar Kompetensi memahami konsumsi, tabungan dan investasi dengan kompetensi dasar mendeskripsikan fungsi konsumsi dan fungsi tabungan pada materi fungsi konsumsi dan fungsi tabungan dan hubungan antara konsumsi dan tabungan mengalami peningkatan, yaitu dilihat dari rata-rata hasil post test pertemuan pertama 65 dan pada pertemuan kedua nilai reratanya menjadi 71,39 , berarti terjadi peningkatan 6,36 dan nilai rata-rata keseluruhan dari 2 kali pertemuan adalah 68,20 dengan kategori cukup.

Kecilnya peningkatan hasil belajar ekonomi siswa kelas X-1 pada post test siklus I ini antara lain disebabkan karena proses pelaksanaan pembelajaran dengan metode pembelajaran kooperatif pada pelajaran ekonomi ini belum bisa berjalan dengan baik, siswa belum terbiasa dengan metode pembelajaran yang diterapkan, masih terdapat siswa yang belajar secara individu dalam kelompoknya. Siswa belum terbiasa mencari pemecahan masalah yang dihadapi dalam mengerjakan soal, serta siswa kurang 
teliti dalam mengarjakan soal sehingga banyak terjadi kesalahan dalam mengerjakan soal separti mengubah fungsi konsumsi ke fungsi tabungan, ataupun sebaliknya.

Pertemuan kedua pada siklus I hasil belajar siswa sudah menunjukkan peningkatan dengan nilai reratanya 71,39. untuk lebih jelasnya peningkatan hasil belajar siswa dapat dilihat pada grafik 2 dibawah ini:

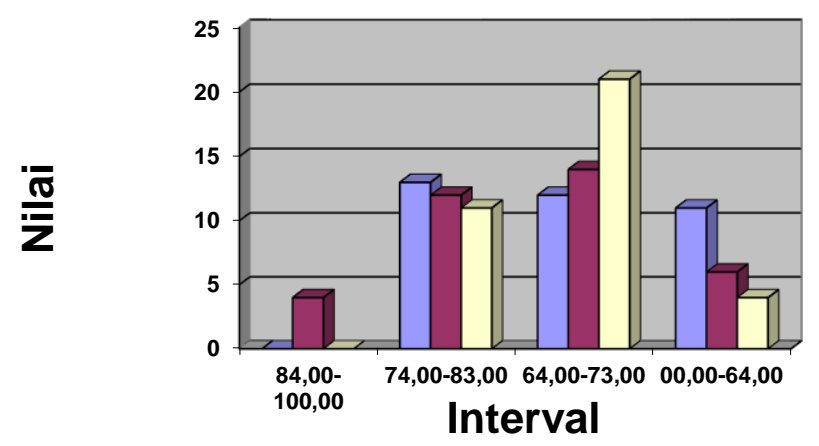

$\square$ Post Test 1 Post Test $2 \square \mathrm{UH}$

Grafik 2. Daya Serap Siswa Melalui Post Test danUlangan Harian pada Siklus I

Dari grafik 2 di atas, dapat diketahui bahwa hasil belajar siswa pada post test I dibandingkan dengan hasil belajar pada post test II telah terjadi peningkatan yaitu siswa yang memperoleh nilai 84,00-10,00 sebanyak 4 siswa (11\%), nilai 74,00-83,00 sebanyak 12 siswa (33\%), nilai 64,00-73,00 sebanyak 14 siswa (39\%), dan nilai 00,0064,00 sebanyak 6 siswa (17\%) dari 36 siswa yang hadir. Meningkatnya hasil belajar siswa ini dikarenakan siswa sudah mulai terbiasa dengan metode pembelajaran kooperatif tipe STAD yang diterapkan, siswa terlihat sudah mulai aktif dan bersemangat dalam berdiskusi, saling bertukar pikiran dan saling menanggapi. Siswa sudah mulai bersaing untuk mendapatkan nilai tertinggi dan berusaha agar kelompoknyalah yang mendapatkan predikat sebagai kelompok terbaik.

Berdasarkan tabel dan grafik yang sama diatas, hasil belajar siswa pada ulangan harian perama juga mengalami peningkatan. Pada ulangan harian pertama ini siswa dengan kategori baik sebanyak 11 siswa (30,56\%), kategori cukup 21 siswa $(58,35 \%)$ dan kategori kurang sebanyak 4 siswa $(11,11 \%)$ dari 36 siswa yang hadir dengan reratanya 71,94 dan dikategorikan cukup. Kemudian data dari ulangan harian I tersebut akan didapat nilai perkembangan dan penghargaan kelompok seperti pada lampiran 12 dan kelompok yang mendapat predikat super akan mendapat penghargaan 
atas prestasi yang diperolehnya dan sebagai bentuk motivasi agar setiap siswa berusaha semaksimal mungkin untuk menjadikan kelompoknya berpredikat super, yang pada intinya dapat juga meningkatkan hasil belajar mereka. Dan inilah yang menjadi ciri dari pembelajaran kooperatif yang diterapkan.

Terjadinya peningkatan hasil belajar siswa menunjukkan bahwa siswa telah mengerti dan memahami proses pembelajaran berdasarkan metode pembelajaran kooperatif tipe STAD. Peningkatan hasil belajar ini tidak terlepas dari aktifitas belajar siswa dan peran guru dalam proses pembelajaran melalui metode pembelajaran langsung. Dan keberhasilan proses belajar itu pada prinsipnya menurut Ishaq (2002:89) adalah keberhasilan yang dicapai baik oleh guru maupun siswa dalam suatu kegiatan pengajaran. Taraf keberhasilan tersebut tentunya sesuai dengan tingkat kemampuan siswa itu sendiri.

\section{Daya Serap Siswa Pada Siklus II}

Daya serap siswa pada siklus II pada standar kompetensi memahami konsumsi dan investasi dengan kompetensi dasar mendeskripsikan fungsi konsumsi dan fungsi tabungan pada materi fungsi investasi dan faktor-faktor penentu tingkat investasi dengan menggunakan metode pembelajaran kooperatif tipe STAD dapat dilihat pada tabel berikut:

Tabel 5. Daya Serap Siswa Pada Siklus II setelah Mengikuti Pembelajaran Kooperatif Tipe STAD

\begin{tabular}{|c|c|c|c|c|c|}
\hline \multirow[t]{2}{*}{ No } & \multirow{2}{*}{$\begin{array}{c}\text { Tingkat } \\
\text { Penguasaan }\end{array}$} & \multirow[t]{2}{*}{ Kategori } & \multicolumn{2}{|c|}{ Post Test Pertemuan Ke } & \multirow{2}{*}{$\begin{array}{c}\text { Ulangan } \\
\text { Harian } \\
\text { N\% }\end{array}$} \\
\hline & & & $\frac{1}{\mathrm{~N} \%}$ & $\stackrel{2}{\mathrm{~N} \%}$ & \\
\hline 1 & $84,00-100,00$ & Amat Baik & $9(25 \%)$ & $11(30,56 \%)$ & $11(30,56 \%)$ \\
\hline 2 & $74,00-83,00$ & Baik & $15(41 \%)$ & $18(50 \%)$ & $10(27,78 \%)$ \\
\hline 3 & $64,00-73,00$ & Cukup & $6(17 \%)$ & $3(8,33 \%)$ & $13(36,11 \%)$ \\
\hline 4 & $00,00-64,00$ & Kurang & $6(17 \%)$ & $4(11,11 \%)$ & $2(5,55 \%)$ \\
\hline \multirow{4}{*}{\multicolumn{3}{|c|}{$\begin{array}{c}\text { Jumlah } \\
\text { Rerata } \\
\text { Rata-rata } \\
\text { Kategori }\end{array}$}} & $36(100 \%)$ & $36(100 \%)$ & $36(100 \%)$ \\
\hline & & & 71,70 & 78,19 & \multirow{3}{*}{$\begin{array}{c}78,61 \\
\text { Baik }\end{array}$} \\
\hline & & & \multicolumn{2}{|c|}{74,95} & \\
\hline & & & \multicolumn{2}{|c|}{ Baik } & \\
\hline
\end{tabular}

Sumber: Data Olahan

Berdasarkan tabel 5 di atas, hasil belajar siklus kedua dibandingkan dengan hasil belajar siklus pertama mengalami peningkatan, dapat dilihat nilai rerata post test pertemuan pertama pada siklus kedua yaitu 71,70 dan rerata pada pertemuan kedua adalah 78.19 dengan nilai rata-rata keseluruhan dari kedua kali pertemuan adalah 74,95 
dengan kategori baik. Walaupun peningkatan dari nilai reratanya hanya mencapai 6,49, namun jika dilihat dari jumlah siswa yang telah banyak memenuhi kriteria ketuntasan minimun yaitu 65,00, bahkan ada yang mencapai nilai dari kriteria ketuntasan minimum. Untuk lebih jelasnya perkembangan nilai hasil belajar tersebut dapat dilihat dari grafik 3 berikut ini:

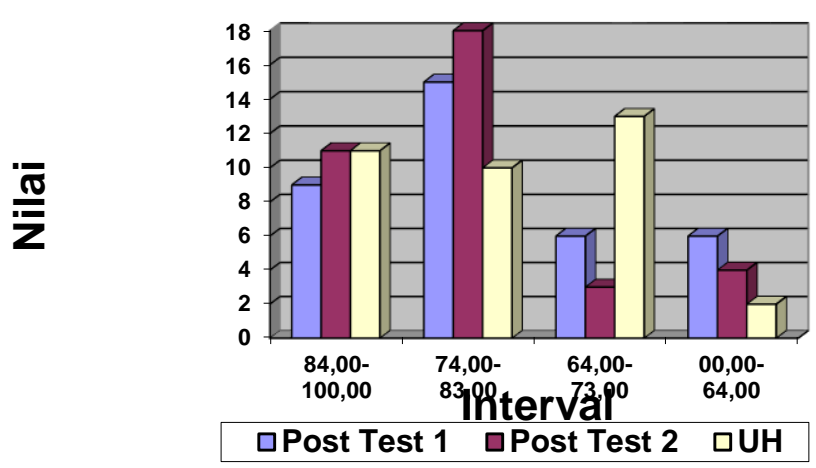

Grafik 3. Daya Serap Siswa Melalui Post Test dan Ulangan Harian pada Siklus II

Dari grafik 3 di atas, dapat dilihat bahwa yang memperoleh nilai 84,00-100,00 pada post test I sebanyak 9 siswa (25\%), post test II 11 siswa $(30,56 \%)$ kenaikan sebesar 5,56\%. Kemudian yang memperoleh nilai 74,00-83,00 pada post test I sebanyak 15 siswa (41\%), post test II 18 siswa (50\%) kenaikannya sebesar 9\%. Kemudian yang memperoleh nilai 64,00-73,00 pada post test I sebanyak 6 siswa (17\%) dan pada post test II sebanyak 3 siswa $(8,33 \%)$ kenaikannya sebesar $8,67 \%$. Kemudian yang memperoleh nilai 0,00-64,00 pada post test I sebanyak 6 siswa (17\%) dan pada post test II sebanyak 4(11,11\%) kenaikannya sebesar 5,89\% dari siswa yang hadir. Hal ini menunjukkan adanya peningkatn hasil belajar disetiap pertemuan melalui penggunaan metoda pembelajaran kooperatif tipe STAD ini.

Peningkatan hasil belajar disebabkan siswa sudah terbiasa degan metode pembelajaran kooperatif tipe STAD yang diterapkan. Siswa sangat menikmati metode pembelajaran yang mengajak siswa untuk saling berbagi dengan temannya. Ulangan harian pada siklus kedua ini juga terjadi peningkatan, jumlah siswa yang telah mencapai kriteria ketuntasan minimum semakin bertambah banyak bila dibandingkan ulangan harian pada siklus I yaitu jumlah siswa yang memperoleh nilai 84,00-100,00 sebanyak 11 siswa $(30,56 \%)$, nilai 74,00-83,00 sebanyak 10 siswa $(27,78 \%)$, nilai $64,00-73,00$ sebanyak 13 siswa $(36,11 \%)$ dan nilai 0,00-64,00 sebanyak 2 siswa $(5,5 \%)$. Kemudian 
siswa yang belum lulus tersebut harus mengikuti ramedial (perbaikan) untuk memperoleh ketuntasan individual.

Setelah data dari hasil ulangan harian diperoleh akan diperoleh nilai perkembangan dan penghargaan kelompok seperti pada lampiran 12.1 dan kelompok yang akan mendapat predikat super akan mendapatkan hadiah sebagai bentuk penghargaan agar siswa lebih meningkatkan aktifitasnya dalam belajar, yang akhirnya dapat meningkatkan hasil belajar mereka.

\section{Ketuntasan Belajar Siswa}

Ketuntasan belajar siswa pada mata pelajaran Ekonomi yang terdiri dari 2 siklus dapat dilihat pada tabel berikut ini:

Tabel 6. Ketuntasan Belajar Siswa pada Siklus I dan II Berdasarkan Nilai Ulangan Harian Setelah Menggunakan Metode Pembelajaran Kooperatif Tipe STAD

\begin{tabular}{|c|c|c|c|c|c|}
\hline Siklus & $\begin{array}{c}\text { Jumlah } \\
\text { siswa yang } \\
\text { hadir }\end{array}$ & $\begin{array}{c}\text { Jumlah } \\
\text { siswa yang } \\
\text { tuntas }\end{array}$ & $\begin{array}{c}\text { Jumlah } \\
\text { siswa yang } \\
\text { tidak tuntas }\end{array}$ & $\begin{array}{c}\text { Presentasi } \\
\text { ketuntasan } \\
\text { balajar }\end{array}$ & kategori \\
\hline I & 36 & 32 & 4 & 88,89 & Tuntas \\
\hline II & 36 & 34 & 2 & 94,44 & Tuntas \\
\hline
\end{tabular}

Sumber : Data Olahan

Berdasarkan tabel 6 di atas, ketuntasan belajar siswa pada siklus I dikatakan tuntas dengan kategori $88,89 \%$. Hanya terdapat 4 orang siswa yang tidak tuntas secara individual namun secara klasikal telah tuntas dan pada siklus II juga dinyatakan tuntas dengan presentasi 94,44\%, terdapat 2 orang siswa yang tidak tuntas secara individual, sedangkan secara klasikal telah tuntas.

Ketuntasan belajar siswa pada siklis I dan II berdasarkan hasil ulangan harian mengalami peningkatan yaitu sebesar 5,55\% dari 88,89\% pada siklus I menjadi $94,44 \%$ pada siklus II. Ada beberapa siswa yang tidak tuntas dapat diketahui dari nilai ulangan harian yang diberikan < 65,00. Ini disebabkan selama proses pembelajaran siswa tersebut tidak memanfaatkan kegiatan kelompok, seperti tidak berdiskusi dengan teman kelompoknya tentang kesulitannya dalam memahami materi, tidak bertanya kepada teman kelompoknya maupun guru.

Menurut Ishaq (2002:46), ketuntasan belajar siswa dikatakan tuntas secara klasikal apabila suatu kelas telah mencapai skor $85 \%$ dari jumlah siswa yang tuntas. Dan siswa yang dikatakan tuntas secara individu apabila telah mencapai nilai kriteria ketuntasan minimun yaitu 65,00 maka siswa tersebut dikatakan tuntas. Dengan demikian pendekatan pembelajaran kooperatif tipe STAD ini dapat meningkatkan hasil 
belajar siswa pada mata pelajaran ekonomi di kelas X-1 SMA YLPI Perhentian Marpoyan Pekanbaru.

Untuk siswa yang belum tuntas, yaitu siswa yang mendapatkan nilai $<65,00$ ditindak lanjuti dengan pemberian tugas atau latihan oleh guru. Ini sesuai yang diungkapkan oleh Ishaq (2002:88), jika siswa tidak mencapai tingkat keberhasilan yang ditentukan maka siswa tersebut tidak dapat meneruskan pelajaran berikutnya, dan harus melakukan program perbaikan telebih dahulu.

\section{SIMPULAN}

Berdasarkan hasil analisis dan pembahasannya dalam penelitian ini dapat ditarik beberapa kesimpulan bahwa dengan menggunakan model pembelajaran kooperatif tipe STAD dapat meningkatkan kemampuan siswa secara individu dalam menyerap materi pembelajaran yang telah diberikan. Hal ini terbukti dari tes yang telah dilakukan pada siklus I rata-rata daya serap siswa dilihat dari nilai ulangan harian mencapai 71,94 dengan kategori cukup. Kemudian pada siklus II rata-rata daya serap siswa mencapai 78,61 dengan kategori baik. Dengan menggunakan model pembelajaran kooperatif tipe STAD ternyata dapat meningkatkan baik proses maupun hasil pencapaian batas penguasaan pada standar kompotensi memahami konsumsi dan investasi kelas X-1 SMA YLPI. Dapat dilihat dari hasil pelaksanaan 2 siklus yaitu pada siklus pertama siswa yang tuntas sebanyak 32 siswa $(88,89 \%)$ dan siswa yang tidak tuntas sebanyak 4 siswa $(11,11 \%)$ dari 36 siswa yang hadir. Sedangkan pada siklus kedua siswa yang tuntas sebanyak 34 siswa $(94,44 \%)$ dan siswa yang tidak tuntas sebanyak 2 siswa $(5,56 \%)$ dari 36 siswa yang hadir. Model pembelajaran kooperatif tipe STAD ternyata juga terbukti dapat meningkatkan keterlibatan atau aktivitas siswa dari masing-masing indikator semakin meningkatkan disetiap kali pertemuannya. Siklus I rata-rata aktivitas siswa mencapai $70,75 \%$ dengan kategori cukup, kemudian pada siklus II meningkat menjadi 86,17 \% dengan kategori amat baik.

\section{DAFTAR PUSTAKA}

Mulyasa, E. 2006. Kurikulum Berbasisi Kompetensi. Konsep, Karakteristik, dan Implementasi. Bandung : PT. Remaja Rosdakarya.

Syah, Muhibbin. 2007. Psikologi Belajar. Jakarta : Rajawali Pers 
Djamarah S.B. 2002. Psikologi Belajar. Jakarta : Rineka Cipta

Slavin, Robert E. 2011. Cooperative learning. Bandung: Nusa Media.

Sugiono. 2010. Metode penelitian pendidikan. Alfabeta: Bandung 